\title{
Serum antibodies to type II collagen in rheumatoid arthritis: comparison of 6 immunological methods and clinical features
}

\author{
R. B. CLAGUE, S. A. FIRTH, P. J. L. HOLT, J. SKINGLE, * \\ C. L. GREENBURY, ${ }^{*}$ AND M. WEBLEY†
}

From the Department of Rheumatology, University of Manchester Medical School, Stopford Building, Oxford Road, Manchester; *Pathology Laboratory, Stoke Mandeville Hospital; and †Oxford Regional Rheumatic Diseases Research Centre, Stoke Mandeville Hospital, Aylesbury, Bucks

SUMMARY A collaborative study of 75 selected patients with rheumatoid arthritis (RA) employing 6 different methods for the detection of antibodies to type II collagen showed highly significant correlations between all the assays. The radioimmunoassays showed a greater sensitivity than either the passive haemagglutination or immunofluorescent techniques, and when the native collagen molecule was heat-denatured a higher number of patients showed increased antibody levels. In 33 patients the measurement of serum antibody levels to human, bovine, and rat native type II collagen showed a lack of species specificity, indicating that heterologous collagens can be employed in these assays. A retrospective analysis of the clinical, laboratory, and radiological features in the 41 patients with raised antibody levels and the 34 patients with normal antibody levels showed very few differences, but there was a significantly lower incidence of subcutaneous nodules (24\% versus $56 \%$ ) in patients with raised antibody levels. This study emphasises the need to standardise assays for the measurement of serum antibody levels to native type II collagen. More extensive studies will be required before the clinical significance of these antibodies can be fully established.

Elevated serum antibody levels to collagen have been detected in patients with rheumatoid arthritis (RA) with different types and species of collagen and a variety of immunological methods. ${ }^{1-7}$ These differences have led to a marked variation in the reported incidence of these antibodies in patients with RA and have led to difficulties in determining their significance.

The restricted distribution of type II collagen to articular cartilage, the vitreous humour of the eye, and the intervertebral discs makes this collagen of particular relevance in the chronic inflammatory arthritides when compared with the more universal distributions of types I and III collagens. ${ }^{8}$ Evidence that antibodies to type II collagen may play a pathogenic role in RA is suggested by studies on native type II collagen-induced arthritis in rats and mice..$^{9-11}$

Our laboratories have independently developed different immunological methods to detect elevated

Accepted for publication 10 October 1982.

Correspondence to Dr R. B. Clague, Department of Rheumatology, University of Manchester Medical School, Stopford Building, Oxford Road, Manchester M13 9PT. serum antibody levels to native type II collagen. ${ }^{4} 67 \mathrm{We}$ have therefore carried out a collaborative study using 6 immunological methods to determine their intercorrelations in detecting serum antibody levels to type II collagen in a selected group of patients with RA. We have looked at the species specificity of these antibodies in a further group of patients. A retrospective analysis of the clinical features of patients with or without elevated serum antibody levels to native type II collagen was also carried out in an attempt to determine their significance.

\section{Patients and methods}

\section{PAT IE N T S}

Sera. Each of the collaborating units provided 50 coded sera containing a high proportion of patients known to have elevated serum antibody levels to native type II collagen by the routine assay employed in that laboratory (see below), which allowed analysis of $\mathbf{1 0 0}$ sera. When all the assays had been completed, the results and codes were exchanged by post simultaneously. Sera from 33 patients with RA were used in the solid-phase radioimmunoassay to determine serum 
IgG antibody levels to human, bovine, and rat native type II collagen.

Sera were analysed from 78 patients with RA (with 5 samples being duplicated), 10 normal healthy controls, 4 hospital controls, and 3 other patients known to possess antibodies to type II collagen (one with osteoarthritis, one with an undiagnosed arthritis, and one with neoplasia). After completion of the immunological studies the clinical data were extracted from the patients' clinical records on a proforma. Full information was available on 75 patients with RA, and this was analysed by dividing the patients into 2 groups according to whether the patient had normal or elevated serum antibody levels to native type II collagen by radioimmunoassay.

\section{METHODS}

The following 3 assays were carried out in the Pathology Laboratory, Stoke Mandeville Hospital.

IF. An indirect immunofluorescent technique using

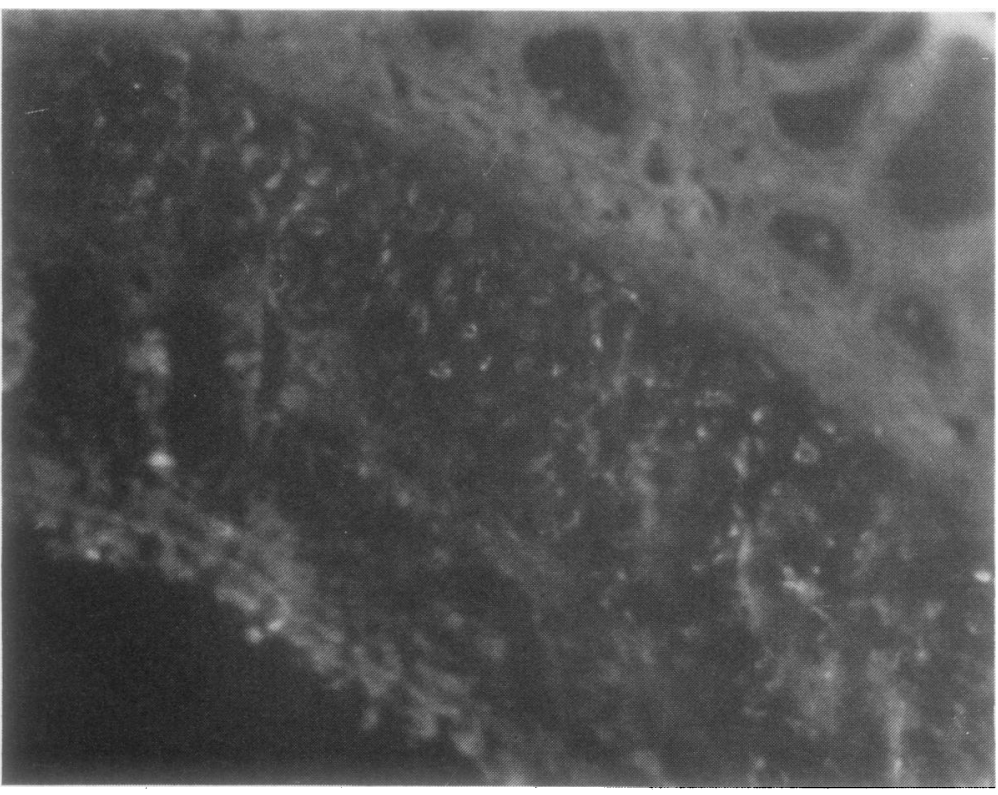

Fig. 1 Immunofluorescent staining of rat tracheal cartilage from a negative serum at dilution of 1 in $8 .(\times 176)$.

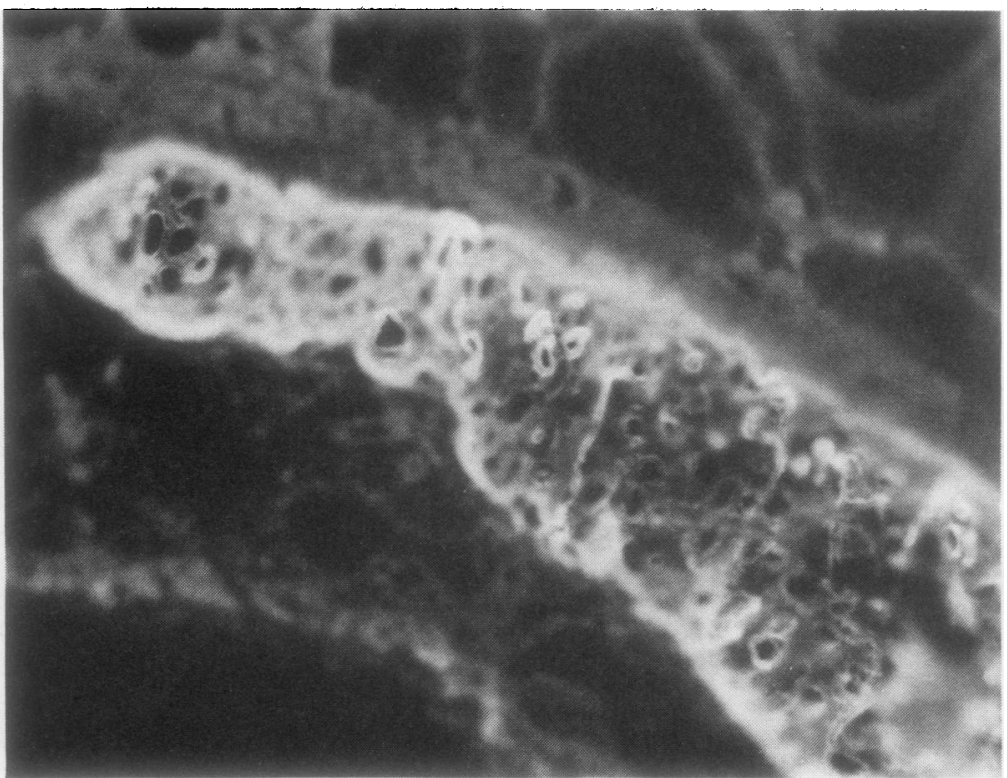

Fig. 2 Immunofluorescent staining of rat tracheal cartilage from a positive serum at dilution of 1 in $8 .(\times 176)$. 
fluorescein-conjugated anti-human $\operatorname{IgG}$ on rat tracheal cartilage. ${ }^{4}$ This assay has been in routine use since 1975. Figs. 1 and 2 show photographs of the immunofluorescent staining of rat tracheal cartilage from a negative and positive sera.

$H A$. A passive haemagglutination technique using native type II collagen extracted from the nucleus pulposus of the intervertebral disc of patients and kindly supplied by Dr Helen Beard (Charles Salt Research Centre, Oswestry). ${ }^{5}$

$H B$. The same passive haemagglutination technique but using native type II collagen extracted from bovine nasal cartilage (supplied by the other collaborating laboratory).

The following 3 radioimmunoassays were carried out in Manchester.

Nat. II. This is a modification of the solid-phase radioimmunoassay for the detection of serum $\mathrm{IgG}$ antibodies to native type II collagen extracted from bovine nasal cartilage. ${ }^{22}$ This includes the incorporation of $0.05 \%$ Tween 20 in all steps of the assay except the initial coating of the tubes with native type II collagen. Sera are also added concurrently to tubes coated with bovine serum albumin alone, and the result obtained from these tubes is subtracted from the result obtained in the native type II collagen tubes to allow for nonspecific binding of immunoglobulins. The result represents specific IgG antibody levels to native type II collagen.

To determine whether the antibodies to native type II collagen showed species specificity the tubes were coated with collagen from 3 different species. The concentrations of the collagen solution were checked by optical density $\left(\mathrm{OD}_{235}\right)$ to ensure that the concentrations were identical before coating the tubes. The tubes were coated with either bovine (extracted from nasal cartilage), human (extracted from articular cartilage), or rat (extracted from Swarm chondrosarcoma) ${ }^{13}$ native type II collagens, and the assay was performed in the usual manner.

Den. II. The methodology of this radioimmunoassay is identical to that of nat. II, except that the native type II collagen was denatured by heating to $45^{\circ} \mathrm{C}$ for 20 minutes immediately before addition to the tubes. The result represents specific $\lg G$ antibody levels to denatured type II collagen.

Cart. Uniform cubes (approximately $2 \mathrm{~mm}$ ) of bovine nasal cartilage were cut with an adapted agar gel trough cutter. These were placed into individual tubes and stored overnight in phosphate-buffered saline (PBS) containing sodium azide. On the following day the cubes of cartilage were rinsed in PBS and $25 \mu \mathrm{l}$ serum followed by $200 \mu \mathrm{l} 0 \cdot 1 \%$ bovine serum albumin (BSA) in PBS, $0.05 \%$ Tween 20 was added. and the cubes were incubated overnight at $4^{\circ} \mathrm{C}$. After 3 further washes in PBS - Tween, $1 \mu \mathrm{g}{ }^{125} \mathrm{I}$ anti-human
IgG was added in $200 \mu \mathrm{l} 0 \cdot 1 \% \mathrm{BSA}$ in PBS -Tween and incubated at room temperature for 4 hours. After a further 3 washes in PBS -Tween the cubes were transferred to new tubes and counted in a gamma counter. The results were calculated after subtracting a BSA control $(\approx 2 \%$ of total radioactivity added), and represented as a percentage binding of the highest serum (this represented $\approx 14 \%$ of total radioactivity added).

Statistics. The upper limits of normal in the radioimmunoassays were calculated as the mean +3 $\mathrm{SD}$ in 15 normal healthy control sera. The correlations between the immunological assays were calculated by the Kendall rank correlation coefficient. Analysis of the differences in the clinical features between the 2 groups of patients was performed by chi-squared analysis. ${ }^{14}$

\section{Results}

IMMUNOLOGICAL ASSAYS

The upper limit of normal for each assay is shown in Table 1. All 10 normal healthy controls and the 4 hospital controls had levels below this limit in all 6 assays. The other 3 patients without apparent RA continued to show elevated antibody levels by one or more assays. The patient with osteoarthritis had a markedly elevated serum IgG antibody level to denatured type II collagen $(4.18 \mathrm{mg} / \mathrm{l})$ only. The patient with the undiagnosed arthritis had elevated antibody levels in all 6 assays. There was good agreement between the 5 duplicated sera (data not shown).

The numbers of normal or elevated serum antibody levels in each assay in the 75 patients with RA are shown in Table 1. The correlations between assays in

Table 1 Number of normal and elevated serum antibody levels to type II collagen in the 75 patients with RA by the 6 different assays

\begin{tabular}{lcccccc}
\hline Method & Den. II & Nat. II & Cart. & IF & $H A$ & $H B$ \\
\hline Upper limit & & & & & & \\
$\quad$ of normal & $<1300 \mu \mathrm{g} / 1$ & $<234 \mu \mathrm{g} / \mathrm{l}$ & $<15 \cdot 6 \%$ & $<8$ & $<8$ & $<8$ \\
Elevated & 54 & 41 & 40 & 31 & 37 & 28 \\
Normal & 21 & 34 & 35 & 44 & 38 & 47 \\
\hline
\end{tabular}

Table 2 Kendal rank correlation coefficient* between the different assays used for measuring serum antibody levels to type II collagen in the 75 patients with $R A$

\begin{tabular}{llllll}
\hline & $H A$ & $H B$ & IF & Cart. & Nat. II \\
\hline Den. II & 0.36 & 0.36 & 0.45 & 0.38 & 0.48 \\
Nat. II & 0.70 & 0.64 & 0.64 & 0.70 & \\
Cart. & 0.68 & 0.60 & 0.63 & & \\
IF & 0.69 & 0.60 & & & \\
HB & 0.78 & & & & \\
\hline
\end{tabular}

${ }^{*} \mathrm{p}<0.001$ for all values. 
these patients are shown in Table 2. These correlations were all highly significant $(\mathrm{p}<0.001)$, though the correlations of the assays with serum antibody levels to denatured type II collagen were lower than with the other assays.

Figs. 3-6 illustrate some of these correlations as well as highlighting some of the differences in the assays. There was a good correlation between the anti-

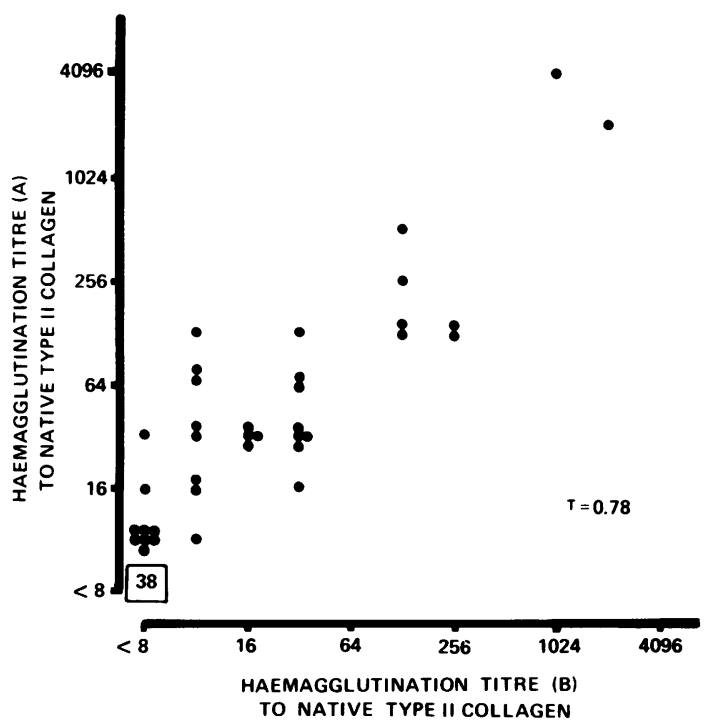

Fig. 3 Correlation between serum antibody levels to native type II collagen extracted from either $(A)$ human nucleus pulposus or $(B)$ bovine nasal cartilage, measured by the passive haemagglutination technique in 75 patients with $R A$.

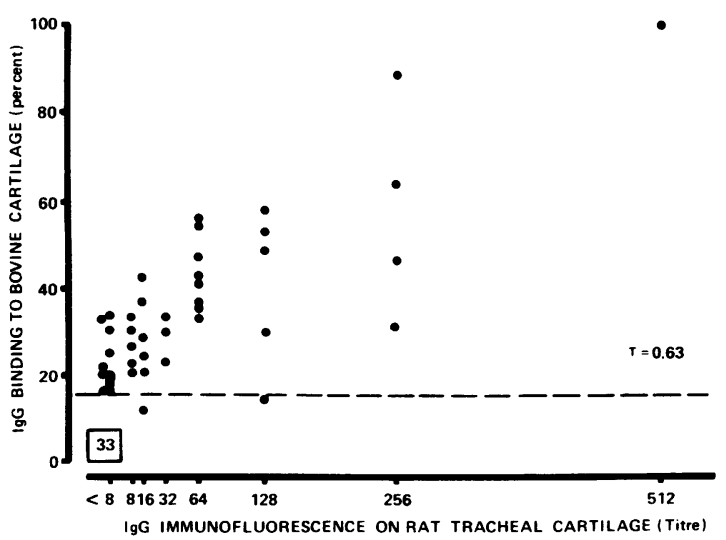

Fig. 4 Correlation between serum IgG antibody levels to bovine nasal cartilage measured by radioimmunoassay and serum IgG antibody levels by immunofluorescence on rat tracheal cartilage in 75 patients with $R A$. body levels to native type II collagens extracted from different species and sources (Fig. 3), though patients tended to have higher titres by the HA assay. Although there was a good correlation between the antibody levels to cartilage measured by radioimmunoassay (cart) or immunofluorescence (IF) (Fig. 4), more patients had elevated levels by the former method. There was a good correlation between the serum IgG antibody levels to native type II collagen and cartilage measured by radioimmunoassays, with only a few patients showing slightly elevated levels by one method with normal levels by the other method (Fig. 5). The poorer correlation between serum IgG antibody levels to native and denatured type II collagen is shown in Fig. 6. Although only a few patients had slightly elevated serum antibody levels to the native molecule with normal antibody levels to the denatured molecule, 16 patients had elevated antibody levels, often quite high, to the denatured molecule with normal levels to the native molecule. Most patients had higher antibody levels to the denatured molecule even when the antibody levels to the native type II collagen were elevated.

The correlations between the serum antibody levels to human native type II collagen and bovine (Fig. 7) or rat (Fig. 8) native type II collagen in 33 of the patients were good, and statistical analysis showed these correlations to be highly significant (human $\mathrm{v}$. bovine, $\tau=0.77, \mathrm{p}<<0.001$; human $\mathrm{v}$. rat, $\tau=0.76$,

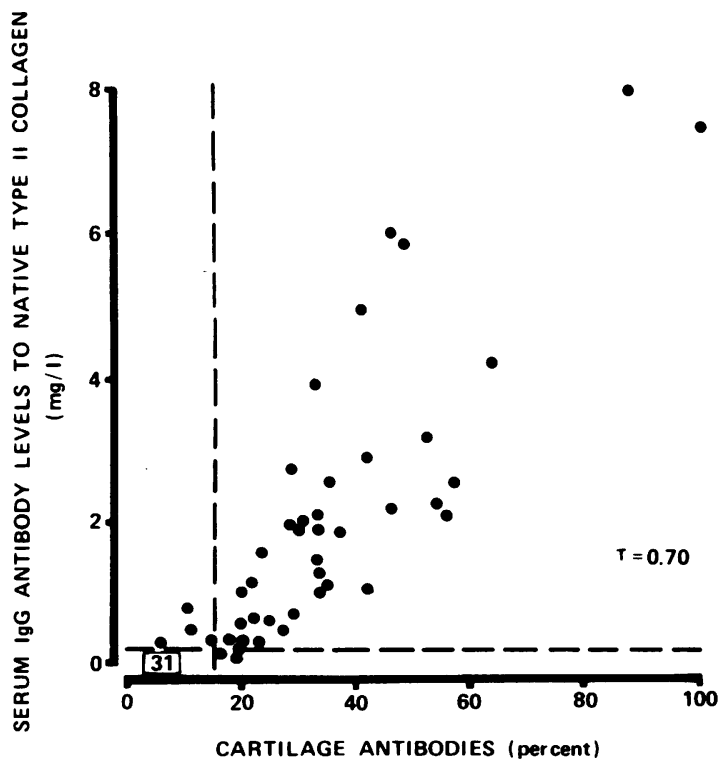

Fig. 5 Correlation between serum IgG antibody levels to native bovine type II collagen and serum IgG antibody levels to bovine nasal cartilage in 75 patients with $R A$. 


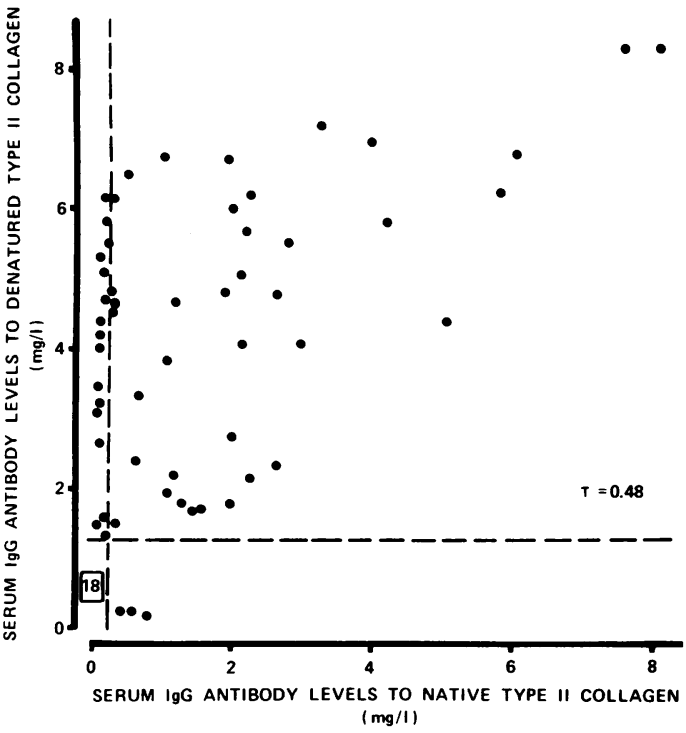

Fig. 6 Correlation between serum IgG antibody levels to denatured and native type II collagen in 75 patients with $R A$.

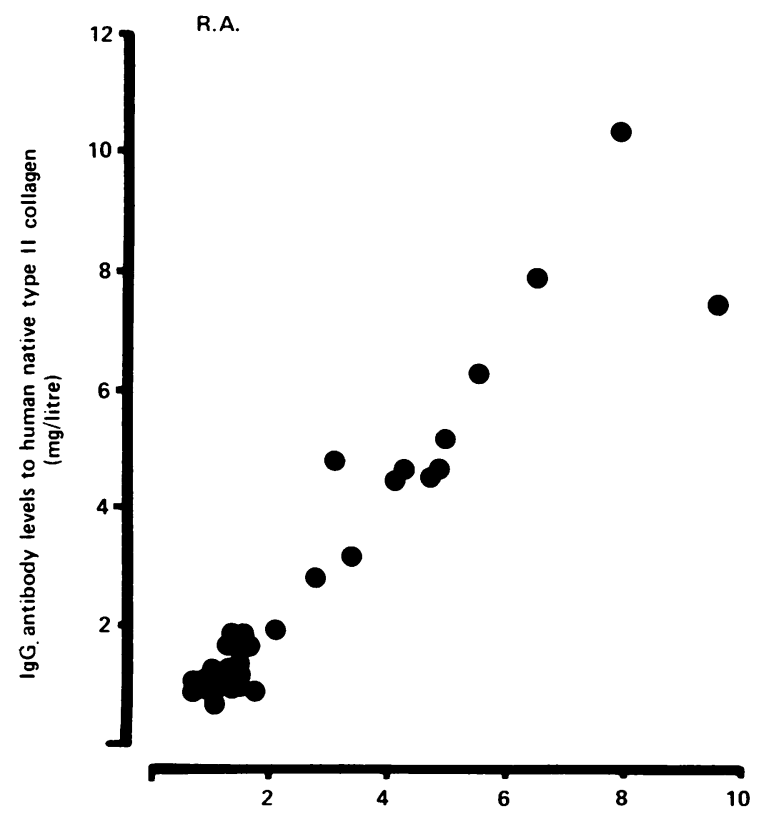

IgG antibody levels to bovine native type II collagen (mg/litre)

Fig. 7 Correlation between serum IgG antibody levels to human and bovine native type II collagens measured by solid-phase radioimmunoassay in 33 patients with $R A$.

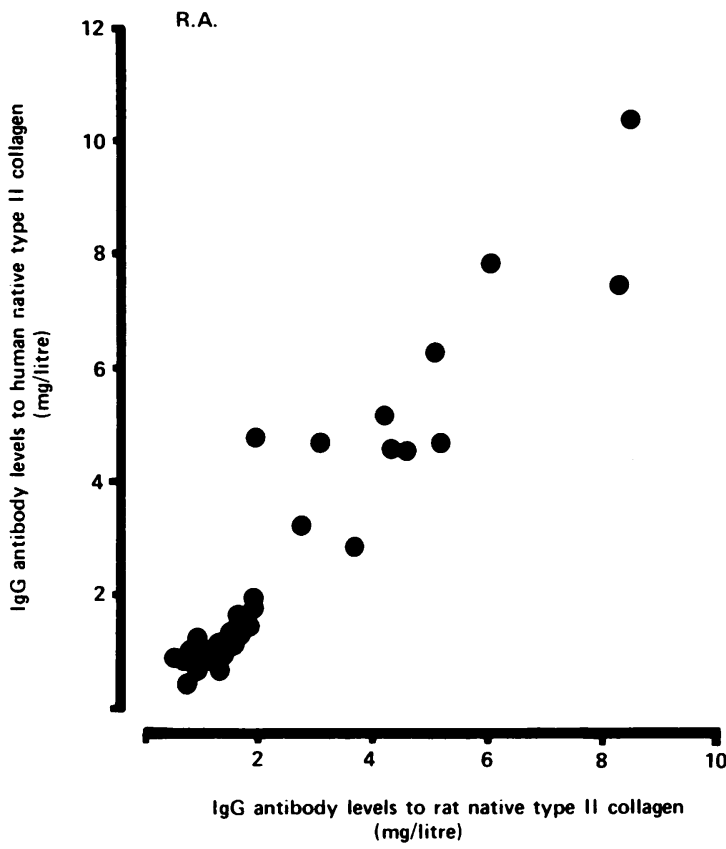

Fig. 8 Correlation between serum IgG antibody levels to human and rat native type II collagens measured by solid-phase radioimmunoassay in 33 patients with $R A$.

$\mathrm{p}<<0.001)$. The slopes of the figures show that antibody levels to human collagen tended to be slightly higher.

\section{CLINICAL FEATURES}

A retrospective analysis of the clinical features was possible in 75 patients with RA, the data being incomplete on the other 3 patients. The clinical features in the 41 patients with elevated serum IgG antibody levels to native type II collagen by radioimmunoassay were compared with those of the 34 patients with normal antibody levels (Table 3). The 2 groups were well matched in most features. There was a lower incidence of subcutaneous nodules in the group with elevated antibody levels $\left(24 \%\right.$ v. $\left.56 \% ; \chi^{2}=6.50, p=0.011\right)$, and the difference between the groups was significant. There was a higher incidence of patients receiving conventional second-line therapy ( $44 \%$ v. $24 \%$ ) and a higher incidence of severe erosive changes on radiology ( $41 \%$ v. $24 \%)$ in the group with elevated antibody levels, though the differences between the groups were not significant.

The details of the other 3 patients with elevated serum antibody levels by one or more assays were also reviewed. The woman with osteoarthritis had no evidence of an erosive arthropathy, though the ESR was elevated at $33 \mathrm{~mm} / \mathrm{h}$. The patient with undiagnosed 
Table 3 Comparison of clinical features between patients with normal or elevated serum antibody levels to native type II collagen by radioimmunoassay

\begin{tabular}{|c|c|c|}
\hline & Normal & Elevated \\
\hline Patients & 34 & 41 \\
\hline Female/male & $20 / 14$ & $26 / 15$ \\
\hline Age & $\begin{array}{l}33-76 \mathrm{yr} \\
\quad(\text { median } 56)\end{array}$ & $\begin{array}{l}18-72 \text { yr } \\
\text { (median 55) }\end{array}$ \\
\hline Duration & $\begin{array}{l}1-31 \text { yr } \\
\text { (median 8) }\end{array}$ & $\begin{array}{l}1-30 \mathrm{yr} \\
\text { (median 6) }\end{array}$ \\
\hline \multicolumn{3}{|l|}{ Diagnosis: } \\
\hline classical RA & 30 & 40 \\
\hline probable RA & 3 & 0 \\
\hline possible RA & 1 & 1 \\
\hline \multicolumn{3}{|l|}{ Joint distribution: } \\
\hline most & 28 & 32 \\
\hline peripheral & 3 & 5 \\
\hline large & 3 & 4 \\
\hline \multicolumn{3}{|l|}{ Treatment: } \\
\hline NSAID alone & 16 & 13 \\
\hline Pen/gold/chloro & $8(24 \%)$ & $18(44 \%)$ \\
\hline Steroids & 10 & 10 \\
\hline Nodules & $19(56 \%)$ & $10(24 \%)$ \\
\hline $\begin{array}{l}\text { Previous joint surgery } \\
\text { Investigations: }\end{array}$ & Investigations: & 11 \\
\hline ESR & $\begin{array}{l}1-115 \mathrm{~mm} / \mathrm{h} \\
(\text { median } \\
39 \mathrm{~mm} / \mathrm{h})\end{array}$ & $\begin{array}{l}3-119 \mathrm{~mm} / \mathrm{h} \\
\text { (median } \\
42 \mathrm{~mm} / \mathrm{h} \text { ) }\end{array}$ \\
\hline Latex +ve & $26(76 \%)$ & $28(68 \%)$ \\
\hline SCAT +ve & $\begin{array}{l}25(74 \%) \\
\text { (median titre } \\
1 \text { in } 128)\end{array}$ & $\begin{array}{l}24(59 \%) \\
\text { (median titre } \\
1 \text { in 64) }\end{array}$ \\
\hline \multicolumn{3}{|l|}{ Erosions: } \\
\hline $\begin{array}{l}\text { none } \\
\text { mild/mod } \\
\text { severe }\end{array}$ & $\begin{array}{c}3(9 \%) \\
23(68 \%) \\
8(24 \%)\end{array}$ & $\begin{array}{r}4(10 \%) \\
20(49 \%) \\
17(41 \%)\end{array}$ \\
\hline
\end{tabular}

arthritis was an elderly man with a seronegative erosive arthritis affecting the distal and proximal interphalangeal joints of both hands and both hips. He also had a left hilar mass and died before a definite diagnosis could be established. The elderly woman with neoplasia had a severe illness characterised by diarrhoea, leg ulcers, and diabetes mellitus, with severe normochromic anaemia and a markedly elevated ESR. She developed an enlarged hard liver with an abdominal mass and was diagnosed as having a colonic neoplasm with hepatic metastases.

\section{Discussion}

The reported incidence of elevated serum antibody levels to collagen in RA has varied greatly (3-71\%) depending on the immunological techniques, types, and species of native or denatured collagen used. ${ }^{1-7}$ It has more recently been suggested that the high incidence of these antibodies may be related to nonantibody serum components such as fibronectin or cold-insoluble globulin. ${ }^{5}$ Several recent studies have reported a lower incidence $(3-5 \%)$ of elevated serum antibody levels to native type II collagen in RA. ${ }^{45} \mathrm{~A}$ modification of our solid-phase radioimmunoassay to allow for nonspecific binding of elevated serum immunoglobulin levels reduced the incidence of serum IgG antibody levels to native type II collagen from $42 \%{ }^{6}$ to $13 \%$ (personal observations). This incidence is still higher than the incidence of $3 \%$ reported with the immunofluorescent technique on rat tracheal cartilage. ${ }^{4}$ In that study there was an obvious but not exact correlation with the passive haemagglutination technique using native type II collagen extracted from nucleus pulposus.

We have therefore compared 6 assays which could be used for the detection of serum antibodies to type II collagen. The sera were specifically selected for this study, so it is impossible to determine the incidence of these antibodies in RA by each assay. There were good correlations between all assays, though the correlations were better between the 5 assays measuring serum antibodies to the native molecule. The good correlations between the antibodies to cartilage, measured by either radioimmunoassay or immunofluorescence, and antibodies to native type II collagen indicate that these antibodies are capable of binding to cartilage, at least in vitro.

There were differences in the numbers of elevated antibody levels in each assay. Among the immunological methods the radioimmunoassays showed the highest numbers of elevated results, suggesting that they had the greatest sensitivity. However, there was also a difference in incidence even when native type II collagen extracted from different species and tissues (bovine nasal cartilage or human nucleus pulposus) was employed in the same immunological method (passive haemagglutination).

The correlations between serum antibody levels to human native type II collagen and bovine or rat native type II collagen measured in all 3 assays (passive haemagglutination and radioimmunoassays) were very similar $(\tau=0.76-0.78)$. These were the best correlations obtained between all assays, indicating that the use of homologous or heterologous collagens produces only a small difference in the antibody levels. This is not surprising, as the helical or conformational determinant of collagen shows very little interspecies variation. ${ }^{15}{ }^{16}$ In all assays more sera gave higher titres to human collagen, suggesting that at least some of the antibody is directed against determinants found only on the human molecule.

The antibody levels to denatured type II collagen were generally higher than to the native molecule together with a higher number of elevated levels in the patients with RA. The upper limit of normal in the control sera was also higher than to the native molecule, though the reason for this is not clear. It is unlikely to be due to fibronectin, as the radioimmunoassay was specifically detecting the binding of 
IgG antibody. It may indicate that these antibodies are directed against antigenic determinants on the denatured molecule which are hidden in the native molecule, but revealed on heat denaturation. The markedly elevated level in the patient with osteoarthritis suggests that this antibody may be more widespread and less specific than antibody to the native molecule and requires further investigation. This may have similarities to antibodies to DNA, where the antibody to double-stranded DNA is specific for systemic lupus erythematosus, whereas antibody to singlestranded (denatured) DNA is less specific. ${ }^{17}$

The significance of these antibodies is uncertain. The restricted distribution of type II collagen, which is mainly found in articular cartilage, might suggest that measurement of serum antibody levels to this antigen may give an indication of the severity of joint destruction (loss of articular cartilage). Support for a pathogenic role of these antibodies is obtained by the induction of an inflammatory polyarthritis in rats and mice following immunisation with this antigen. ${ }^{9-11}$ Immunological studies in this model have shown that a high level of humoral immunity to native type II collagen is often, though not invariably, associated with arthritis, and animals that fail to mount an immune response to this collagen fail to develop arthritis. ${ }^{10}$

In a retrospective analysis of the clinical features there were few differences between the rheumatoid patients with or without elevated serum antibody levels to native type II collagen. The majority of patients in both groups had classical/definite RA and there was a good agreement in most parameters between the 2 groups. There was, however, a significantly lower incidence of subcutaneous (rheumatoid) nodules in this group though the incidence and titres of serum antiglobulins were only slightly lower. Thus on clinical grounds the group of patients with elevated serum antibody levels to native type II collagen could not be delineated as a separate and distinct subset of patients with RA.

It is not known whether these antibodies are merely the result of damage to articular cartilage and thus an index in some patients of the extent of articular damage, or whether they also play a pathogenic role and thus lead to further damage to the articular cartilage.

Evidence for a pathogenic role of these antibodies is supported by 2 studies in native type II collageninduced arthritis in the rat. This arthritis can be induced in naive rats by the passive transfer of serum alone containing antibodies to native type II collagen. ${ }^{18}$ The depletion of serum complement in rats with cobra-venom factor delays the induction of native type II collagen-induced arthritis until the serum complement levels have returned towards normal levels. ${ }^{19}$ These 2 studies suggest a direct role for these anti- bodies in the induction of this arthritis in the rat, but their role in patients with RA remains uncertain.

This study demonstrates the good correlations between the different immunological methods available for measuring serum antibody levels to native type II collagen, though there were differences in the sensitivities of the various assays. This does not account for the wide variation in the reported incidence of these antibodies in RA. Our radioimmunoassays were modified to allow for nonspecific binding of immunoglobulins and this reduced the incidence of antibodies to native type II collagen to a considerable extent. We now feel that the major factor in reporting a high incidence of these antibodies in RA has been the detection of nonspecifically bound immunoglobulins by highly sensitive radioimmunoassays. All sensitive immunological assays should therefore allow for nonspecific binding of immunoglobulins in their methodology.

However, even when nonspecific binding of immunoglobulins is allowed for, there will still be minor variations in the incidence of these antibodies to RA. These will be due to a combination of factors in the methodology and patient selection. The former includes the sensitivity of the immunological method, as well as the species, and the native or denatured state of the collagen. Patient selection could also account for variation as the true incidence of these antibodies in certain racial or ethnic groups with RA, and the effects of therapy on antibody levels are not yet known. Standardisation of these methods, as has already been established for serum antiglobulins, will be necessary before the true incidence of these antibodies can be determined in patients with rheumatoid arthritis. Further long-term studies on patients are required before the significance of these antibodies can be determined.

We thank Mrs D. Ward for typing the manuscript, Mrs S. Roe (Department of Medical Illustrations) for preparing the figures, and Miss Linda Hunt (Faculty of Medicine Computational Group) for statistical analysis.

This work was supported by the Arthritis and Rheumatism Council, the North-Western Regional Area Health Authority, and the Oliver Bird Trust of the Nuffield Foundation.

\section{References}

1 Steffen C, Timpl R. Antigenicity of collagen and its application in the serologic investigation of rheumatoid arthritis sera. Int Arch Allergy Appl Immunol 1963; 22: 333 -49.

2 Michaeli D, Fudenberg $\mathrm{H} \mathrm{H}$. The incidence and antigenic specificity of antibodies against denatured human collagen in rheumatoid arthritis. Clin Immunol Immunopathol 1974; 2: $153-9$.

3 Andriopoulos N A, Mestecky J, Miller E J, Bradley E L. Antibodies to native and denatured collagens in sera of patients with rheumatoid arthritis. Arthritis Rheum 1976; 19: 613 -7.

4 Greenbury C L, Skingle J. Anti-cartilage antibody. J Clin Pathol 1979; 32: 826 -31. 
5 Beard H K, Lea D J, Ryvar R. Anomalous reactions in the haemagglutination assay for anti-collagen antibodies: studies on patients with rheumatoid arthritis or chronic low back pain. $J$ Immunol Methods 1979; 31: 119 -28.

6 Clague $R$ B, Shaw M J, Holt P J L. Incidence of serum antibodies to native type $I$ and type II collagens in patients with inflammatory arthritis. Ann Rheum Dis 1980; 39: 201 -6.

7 Clague R B, Shaw M J, Holt P J L. Incidence and correlation between serum IgG and IgM antibodies to native type II collagen in patients with chronic inflammatory arthritis. Ann Rheum Dis 1981; 40: $6-10$.

8 Gay S, Gay R E, Miller E J. The collagens of the joint. Arthritis Rheum 1980; 23: 937 -41.

9 Trentham D E, Townes A S, Kang A H. Autoimmunity to native type II collagen: an experimental model of arthritis. $J$ Exp Med 1977; 146: 857 -68.

10 Morgan K, Clague R B, Shaw M J, Holt P J L. Native type II collagen-induced arthritis in the rat. 1 . Incidence and humoral response to collagen. Ann Rheum Dis 1980; 39: 285 -90.

11 Courtenay J S, Dallman M J, Dayan A D, Martin A, Mosedale B. Immunisation against heterologous type II collagen-induced arthritis in mice. Nature 1980; 283: $666-8$.

12 Clague R B, Brown R, Weiss J B, Holt P J L. Solid-phase radioimmunoassay for the detection of antibodies to collagen. $J$ Immunol Methods 1979; $27: 31-41$.
13 Smith B D, Martin G R, Miller E J, Swarm R. Nature of the collagen synthesized by a transplanted chondrosarcoma. Arch Biochem Biophys 1975; 166: 181 -6.

14 Siegel S. Non-parametric statistics for the behavioural sciences. London: McGraw-Hill, 1956.

15 Beil W, Timpl R, Furthmayr H. Conformation dependence of antigenic determinants on the collagen molecule. Immunology 1973; 24: 13 -24.

16 Miller E J, Lunde L G. Isolation and characterisation of the cyanogen bromide peptides from the $\alpha 1$ (II) chain of bovine and human articular cartilage collagen. Biochemistry 1973; 12: 3153 -9.

17 Lange A. Evaluation of the simultaneous estimation of anti-ds DNA and anti-ss DNA antibodies for clinical purposes. Clin Exp Immunol 1978; 31: 472 -81.

18 Stuart J M, Cremer M A, Townes A S, Kang A H. Type II collagen-induced arthritis in rats. Passive transfer with serum and evidence that IgG anticollagen antibodies can cause arthritis. J Exp Med 1982; $155: 1$-16.

19 Morgan K, Clague R B, Shaw M J, Firth S A, Twose T M, Holt $P$ J L. Native type II collagen-induced arthritis in the rat: the effect of complement depletion by cobra venom factor. Arthritis Rheum 1981; 24: 1356 -62. 